\title{
Don't be scared, be angry: the politics and ethics of Ebola
}

\begin{abstract}
LClaire Hooker PhD

Christopher Mayes

Postdoctoral Fellow

Chris Degeling

PhD, BVSC

Research Fellow'

Gwendolyn L Gilbert MD, FRACP, FRCPA Clinical Professor ${ }^{1,2}$

lan H Kerridge BMed(Hons), FRACP, FRCPA Director and Associate Professor of Bioethics ${ }^{1,2}$

1 Centre for Values, Ethics and Law in Medicine, University of Sydney, Sydney, NSW.

2 Marie Bashir Institute for Infectious Diseases and Biosecurity, University of Sydney, Sydney, NSW.

claire.hooker@ sydney.edu.au

doi: 10.5694/mjal4.01191

Tis: he current outbreak of Ebola virus disease (EVD) in West Africa is the worst so far. As of 20 August 2014, 2240 confirmed cases and 1229 deaths have been recorded by the World Health Organization. ${ }^{1}$

While the possibility of an EVD outbreak in Australia should not worry us, ${ }^{2}$ the social, economic and political conditions associated with the present outbreak should. EVD has been characterised as an African disease spread through African culture. ${ }^{3}$ However, we argue that many aspects of this outbreak represent a continuation of crises whose root cause lies in neoliberal economic policies that emphasise the free market as the primary driver of economic growth, innovation and allocation of resources. ${ }^{4}$

Two aspects of the outbreak and the way in which it has been managed support this contention. First, the lack of vaccines and medications for EVD is evidence that markets cannot reliably supply treatments for epidemic diseases where the number of affected individuals is small. Second, the public infrastructure needed to prevent and control an infectious disease outbreak has been eroded in many West African nations over the past 40 years. Alongside war, political instability and corruption, the collapse of social infrastructure has resulted from structural adjustment and trade liberalisation programs promoted by the International Monetary Fund (IMF) and the World Bank. We need to understand these political and economic problems as the conditions underlying disease outbreaks. ${ }^{5}$
\end{abstract}

\section{Therapeutic innovation has not trickled down}

Since EVD was identified almost 40 years ago, the scientific community has been able to accelerate research and develop prevention and containment strategies for other worrying emerging infectious diseases, such as those caused by severe acute respiratory syndrome coronavirus, ${ }^{6}$ influenza A(H1N1)pdm09 virus and Hendra virus. So why has this not occurred with Ebola?

Part of the reason is that the normal drivers of drug research and development - pharmaceutical companies operating in a global marketplace - have failed to develop effective treatments or vaccines for highly virulent and destructive diseases affecting only small numbers of very poor people in sporadic outbreaks. Researchers, investors and company directors may recognise humanitarian needs but cannot tolerate the economic risks. Instead, pharmaceutical companies focus on conditions or diseases that involve large markets involving more affluent and regular consumers of their products, where larger profits can be generated. ${ }^{7}$

Nevertheless, despite the economic disincentives, several small companies have been developing drugs and vaccines against EVD. There are products in pretrial readiness, and Phase II clinical trials for promising EVD therapies are expected soon and may have benefit in this

\section{Sunnาary \\ The current outbreak of Ebola virus disease in West Africa is the worst so far. \\ The unprecedented extent of mortality and morbidity in this outbreak has followed more from imposition of neoliberal economic policies on the countries affected than from the biological virulence of Ebola virus. \\ The lack of vaccines and medications for Ebola virus disease is evidence that markets cannot reliably supply treatments for epidemic diseases. \\ - We attribute the current difficulties in containment chiefly to the erosion or non-development of the health and medical infrastructure needed to respond effectively, as a direct result of market-privileging policies imposed in the interests of wealthy nations. \\ These events and responses hold lessons for public health priorities in Australia.}

outbreak. ${ }^{8,9}$ However, it seems that these developments are not motivated primarily by humanitarian considerations - to save African lives - but rather by the desire to safeguard Western nations against emerging infectious diseases and weaponised infectious agents. , $^{10,1}$

\section{Therapeutic innovation is part of a security agenda}

Established by the United States Government after the anthrax attacks of 2001, the Biomedical Advanced Research and Development Authority (BARDA) has stockpiled vast quantities of therapeutic agents in readiness for various forms of perceived biological threat to US citizens. BARDA and the US military medical services, in partnership with hundreds of small biotechnology companies, have developed medical countermeasures against infectious agents with potential for use in terrorist or military activity. Three of the agents funded by these partnerships are in the early stages of development as countermeasures against EVD. Research into ZMapp, the monoclonal antibody therapy given experimentally to a very small number of infected people in the current outbreak, was funded by the US Army Medical Research Institute of Infectious Diseases and Public Health Agency of Canada ${ }^{7}$ as part of this biodefence program. In Australia, the CSIRO (Commonwealth Scientific and Industrial Research Organisation) and US military medical services collaborated to produce the Hendra virus antiserum and related equine vaccine. ${ }^{12}$

These partnerships reflect a worldwide shift of public health focus from disease prevention towards the biosecurity of wealthy nations, their preparedness for disease outbreaks and protection of their economic interests. Lakoff describes two complementary regimes of global health: one focused on security systems that mitigate threats to Western countries, and one focused on humanitarian disease control in the developing world, with 
the second regime functioning as a palliation against the first. ${ }^{13}$ Wealthy nations' stockpiling of medicines in the face of any threat, and the production costs of sophisticated therapies such as ZMapp, , ,7,8 lessen the availability of such medicines to people in impoverished nations. The effect is to reinforce a division between a small, privileged group of wealthy nations and a majority of poorer countries with limited access to needed health resources. Under this current paradigm, it is unclear how much the developing world will benefit in practice from new medications and vaccines.

\section{Inequality extends ethical challenges to therapeutic innovation}

The immediate use of untried experimental medicines has led to a pressing ethical debate on how to best allocate the use of ZMapp. Questions have been raised about why the very limited stock was at first only given to two US citizens and a Spanish citizen, and not to affected people resident in West Africa. ${ }^{14,15}$ Deploying untested products among vulnerable patients in impoverished nations and communities recalls a long history of non-consensual, exploitive drug trials. Ineffective or harmful treatments (as may prove to be the case for ZMapp) would risk a costly breakdown of trust in health care workers and public health programs. The report of an ethics panel, hastily convened by the $\mathrm{WHO}$ - without representatives from West Africa - to advise on these issues underscores the ethical challenges that result from social disparity when confronting experimental interventions in emergency contexts. These challenges include the question of who might authorise the use of experimental treatments - for instance, the Liberian government did not approve the investigational use of drugs. ${ }^{16}$

Comparison of the failure of market incentives to produce widely available and efficacious drugs via the pharmaceutical industry with the success of preserving the biosecurity interests of IMF and G20 member nations reveals a disturbing feature of neoliberal policy making on a global scale. These policies have resulted in privileging the economic and security interests of the nations developing the policies — including Australia — while disempowering those of poor countries and governments.

\section{Infrastructure and the ethics of containment}

Development of effective vaccines and treatments is crucial. However, health care and social infrastructure, resources and behaviour - much more than virulence - determine the extent of mortality and morbidity in an outbreak. We know the importance of health infrastructure and proven and inexpensive infection control measures in containing EVD. ${ }^{5}$ But market-privileging economic and social policies, imposed on West African nations to secure Western economic interests, have eroded needed physical and social infrastructure over decades. ${ }^{3,7}$ Governments of poorer countries accepting structural adjustment program loans from the IMF and World Bank, aiming to increase economic growth, were required to introduce austerity measures, transform agriculture to focus on export commodity crops, reduce tariffs and allow foreign investment. Public infrastructure in disrepair, undercutting of rural livelihoods and increased food insecurity have resulted. ${ }^{17,18}$

In these circumstances, preventing and containing infectious disease outbreaks is very difficult. Most experts cite a lack of even basic sanitary facilities, sterile needles, personal protective equipment and other health infrastructure. Once the disease had spread into dense urban areas and across four nations, the resources of governments and non-government organisations, such as Médecins Sans Frontières, were stretched beyond capacity. ${ }^{19}$

Even former US President Bill Clinton, a proponent of free markets, is one of many who have acknowledged the devastating impact of IMF and World Bank policies on agricultural sectors in Africa and their flow-on effects on social stability, infrastructure and health. ${ }^{20}$ The recent EVD outbreak and the responses to it have not developed inevitably but in circumstances intricately linked to the economic and political interests of resource-rich nations like Australia. ${ }^{3,5,7}$

The international public health response to EVD is humanitarian in focus. But it too is structurally inseparable from the political and economic determinants of the outbreak. ${ }^{21}$ The WHO-coordinated best-practice containment efforts - including advocacy for local health infrastructure and respectful, sensitive partnerships with local healers and communities - has met with some success. ${ }^{22}$ However, the International Health Regulations, which govern WHO disease management and response, are part of the security agenda identified by Lakoff,, 13 in which expensive surveillance systems and response teams are given priority over investment in local disease prevention and public health infrastructure. ${ }^{23,24}$ Meanwhile, aid money remains explicitly within what wealthy nations term "international development" - a process that imposes their economic priorities on local populations. ${ }^{18}$

\section{Containment, culture and economics}

Western media depict African culture, rather than the absence of basic health services and diagnostic laboratories, as a major barrier to containment. ${ }^{3}$ Traditional burial practices are seen to facilitate EVD transmission; likewise, superstitious, ineffectual traditional medicines are perceived to promote risky exposure and/or behaviour conducive to EVD spread. Specific cultural practices are not unimportant, but structural determinants have a much greater overall impact, especially in the crucial early stages when the outbreak spread so widely. Culture has not proven to be such a barrier to containment in the past. ${ }^{3,19}$ In Nigeria, standard control measures, such as patient isolation, personal protective equipment and hospital hygiene, have successfully limited the outbreak so far to 12 people. ${ }^{22}$

In a global response to EVD, research and development of effective drugs should not be the only or even the dominant strategy; EVD can be prevented and contained by standard public health sanitary and hygiene measures. ${ }^{2}$ Investing in better health services is in the interests of all 
West Africans and would be a longer lasting and more effective use of money. This would enable a swift response to this or any other infectious disease outbreak - and, globally, that would be in all our interests.

Though seemingly far removed from Australia, the West African outbreak of EVD has two lessons for us. At the international level, Australia, as a member nation of the IMF and soon-to-be host of the G20, has a role in the effects of neoliberal policies, including the structural adjustment programs in West Africa and in our own region. Australia has a responsibility to ensure its representatives are not pursuing economic or security interests that leave developing nations vulnerable to devastating disease risks.

At a domestic, more tangible level, this outbreak reminds us that Australia needs to maintain the strength of its own public health infrastructure and access to primary care. This requires the Australian Government to invest in, rather than make cuts to, social services, and to maintain public funding for research into areas that commercial interests do not pursue. For example, the recent proposal to cut funding to the $\mathrm{CSIRO}^{25}$ is troubling, as these structural shifts in research funding allocation could have significant long-term impacts on the community's health. It is not so much the fear and chaos of an EVD outbreak that should worry us but the more mundane policy decisions that occur behind closed doors.

Competing interests: No relevant disclosures.

Provenance: Not commissioned; externally peer reviewed.

1 World Health Organization. Ebola virus disease update - west Africa. 19 Aug 2014. http://www.who.int/csr/don/2014_08_19_ebola/en (accessed Aug 2014).

2 Doherty P. How threatened are we by Ebola virus? The Drum 2014; $31 \mathrm{Jul}$ http://www.abc.net.au/news/2014-07-31/doherty-how-threatened-arewe-by-ebola-virus/5638438 (accessed Aug 2014).

3 Jones J. Ebola, emerging: the limitations of culturalist discourses in epidemiology. J Glob Health 2011; 1: 1-6.

4 Harvey D. A brief history of neoliberalism. London: Oxford University Press, 2009.

5 Thompson A. Ebola: an emergency within an emergency. Impact Ethics 2014; 21 Aug. http://impactethics.ca/2014/08/19/ebola-an-emergencywithin-an-emergency (accessed Aug 2014).

6 Ali SH, Keil R, editors. Networked disease: emerging infections in the global city. London and New York: Wiley Blackwell, 2008.
7 Phillips L. The political economy of Ebola. Jacobin 2014; 13 Aug. https:// www.jacobinmag.com/2014/08/the-political-economy-of-ebola (accessed Aug 2014).

8 Dionne KY. Ebola experimental treatment only for the exceptional. Washington Post 2014; 10 Aug. http://www.washingtonpost.com/blogs/ monkey-cage/wp/2014/08/10/ebola-experimental-treatment-only-forthe-exceptional (accessed Aug 2014).

9 World Health Organization. Ebola: experimental therapies and rumoured remedies. 15 Aug 2014. http://www.who.int/mediacentre/news/ebola/15august-2014/en (accessed Aug 2014).

10 Miller JE. Public Health Emergency Medical Countermeasures Enterprise and Project BioShield. In: Pilch RF, Zilinskas RA, editors. Encyclopedia of Bioterrorism Defense. New York: John Wiley and Sons, 2005. doi: 10.1002/0471686786.ebd0188.

11 Trull MC, du Laney TV, Dibner MD. Turning biodefense dollars into products. Nat Biotechnol 2007; 25: 179-184.

12 Middleton D, Pallister J, Klein R, et al. Hendra virus vaccine, a one health approach to protecting horse, human, and environmental health. Emerg Infect Dis 2014; 20: 372-379. doi: 10.3201/eid2003.131159.

13 Lakoff A. Two regimes of global health. Humanity 2010; 1: 59-79.

14 Rid A, Emanuel EJ. Ethical considerations of experimental interventions in the Ebola outbreak. Lancet 2014; Aug 22 [Epub ahead of print]. doi: 10.1016/ S0140-6736(14)61315-5.

15 Schüklenk U. WHO Ebola ethics panel excluded those most affected. The Conversation 2014; 13 Aug. http://theconversation.com/who-ebola-ethicspanel-excluded-those-most-affected-30429 (accessed Aug 2014).

16 Gostin LO, Lucey D, Phelan A. The Ebola epidemic: a global health emergency. JAMA 2014; Aug 11 [Epub ahead of print]. doi: 10.1001/ jama.2014.11176.

17 Moseley WG, Carney J, Becker L. Neoliberal policy, rural livelihoods, and urban food security in West Africa: a comparative study of The Gambia, Côte d'Ivoire, and Mali. Proc Natl Acad Sci U S A 2010; 107: 5774-5779.

18 Harman S. Ebola, polio, HIV: it's dangerous to mix healthcare and foreign policy. The Guardian 2014; 14 Aug. http://www.theguardian.com/globaldevelopment/poverty-matters/2014/aug/14/ebola-polio-hiv-healthcareforeign-policy (accessed Aug 2014).

19 Schwartz D. Ebola outbreak: it's not the virus but Africa that's changed. CBC News 2014; 8 Aug. http://www.cbc.ca/news/health/ebola-outbreak-it-snot-the-virus-but-africa-that-s-changed-1.2729264 (accessed Aug 2014).

20 AP. Bill Clinton: "We blew it" on global food. CBS News 2008; 23 Oct. http://www.cbsnews.com/news/bill-clinton-we-blew-it-on-global-food (accessed Aug 2014).

21 King NB. Security, disease, commerce: ideologies of postcolonial global health. Soc Stud Sci 2002; 32: 763-789.

22 World Health Organization. Ebola situation in Nigeria and Guinea: encouraging signs. 19 Aug 2014. http://www.who.int/mediacentre/news/ ebola/18-august-2014/en (accessed Aug 2014).

23 Davies SE. Securitizing infectious disease. Int Aff 2008; 84: 295-313.

24 Weir L, Mykhalovsky E. Global public health vigilance: creating a world on alert. New York: Taylor and Francis, 2010.

25 Jabour B. CSIRO's next round of cuts could hit Ebola research, warns union. The Guardian 2014; 14 Aug. http://www.theguardian.com/world/2014/ aug/14/csiro-cuts-ebola-research-warns-union (accessed Aug 2014). 